\section{Pulmão do Cuspidor de Fogo}

\author{
Fire-Eater's Lung
}

Apresenta-se o caso de um homem de 31 anos, fumador sem outras doenças conhecidas. É agente comercial numa empresa de produtos de higiene e, desde há 3 meses, iniciou a prática de cuspir fogo em espectáculos de rua.

Recorre ao Serviço de Urgência (SU) por dor torácica anterior direita com características pleuríticas, tosse seca e febre $\left(40^{\circ} \mathrm{C}\right)$, quadro que iniciou poucas horas após a aspiração do líquido "água de fogo" (composto por derivados do petróleo) durante uma performance a cuspir fogo.

Do estudo realizado, apresentava aumento dos marcadores inflamatórios e hipotransparência do lobo médio na radiografia torácica, pelo que teve alta medicado com azitromicina 500mg uma vez dia. Por persistência e agravamento dos sintomas, recorre novamente ao SU 3 dias depois. Objectivadas febre e crepitações no 1/3 inferior do hemitórax direito. TAC torácica a mostrar consolidação do segmento anterior do lobo inferior esquerdo e do segmento medial do lobo médio (Figuras 1 e 2), com áreas de baixa densidade (-77HU) - seta da figura 1-, áreas em vidro despolido no lobo médio (Figura 2) e ainda algumas opacidades lineares nos segmentos basais dos lobos inferiores. Apresentava também aumento franco dos marcadores analíticos de inflamação, com leucocitose 16000/ LL, neutrofilia e PCR 233 mg/L. A gasimetria arterial excluiu insuficiência respiratória. Assumiu-se Pneumonia Lipóide Exógena Aguda com possível sobreinfecção, pelo que iniciou amoxicilina-clavulanato após colheita de rastreio séptico. Realizou broncofibroscopia, que não revelou alterações da mucosa brônquica, e colheu lavado brônquico (LB), tendo-se observado células muco-secretoras, macrófagos alveolares e escassos polimorfonucleares. Não foi isolado agente infeccioso e apresentou evolução clínica e analítica favorável, tendo tido alta após 4 dias de internamento, a completar antibioterapia empírica em ambulatório.

A Pneumonia Lipóide Exógena é uma entidade rara, que resulta da inalação e/ou aspiração de substâncias lipídicas, podendo ocorrer de forma crónica ou aguda, sendo esta última uma condição rara e consequente de aspiração acidental de uma grande quantidade de material lipídico num curto espaço de tempo ${ }^{1}$. Os sintomas mais comuns são tosse, dor torácica, dispneia, febre e hemoptises, sendo habitual surgirem nas primeiras 12 horas após aspiração da substância 1 . 0 melhor método de imagem para o diagnóstico é o TAC de alta resolução, que frequentemente mostra consolidação e/ou áreas em vidro despolido, habitualmente bilateral e nos lobos inferiores (quando unilateral o pulmão direito é o mais afectado), podendo ainda observar-se espessamentos septais interlobulares² 0 achado imagiológico mais característico é a presença de consolidação com áreas de baixa densidade (entre -150 a -30HU), fenómeno que se deve à atenuação da gordura ${ }^{1-4}$. 0 estudo citológico do lavado broncoalveolar pode evidenciar macrófagos xantomatosos, o que corrobora o dignóstico. Contudo, este achado não é específico e os falsos negativos são frequentes ${ }^{1,3}$. 0 diagnóstico é baseado na histórica clínica e nos achados imagiológicos e citológicos, sendo que nenhum isoladamente faz o diagnóstico ${ }^{1}$. Dado ser uma entidade pouco frequente, com poucos casos descritos, o tratamento baseiase na experiência clínica, sendo essencial: a evicção do agente
Figura 1. TAC torácica (janela mediastínica). Consolidação com áreas de baixa densidade no lobo médio (seta)

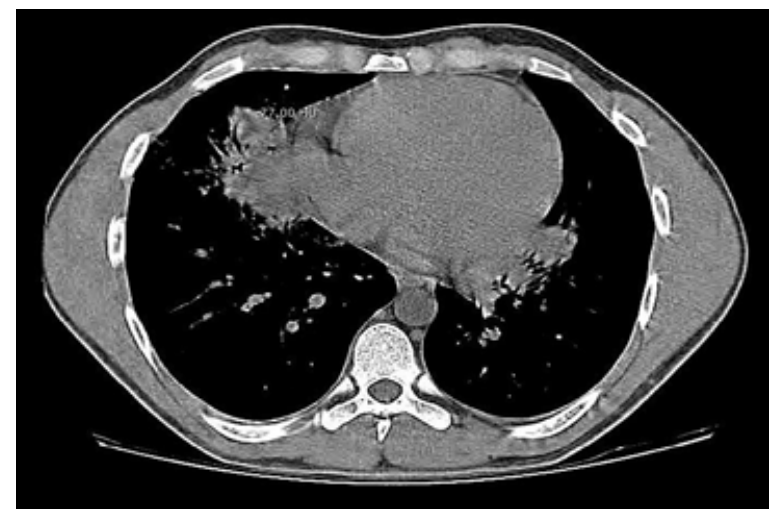

Figura 2. TAC torácica (janela pulmonar). Consolidação do lobo médio e padrão periférico em vidro despolido. Consolidação do segmento anterior do lobo inferior esquerdo

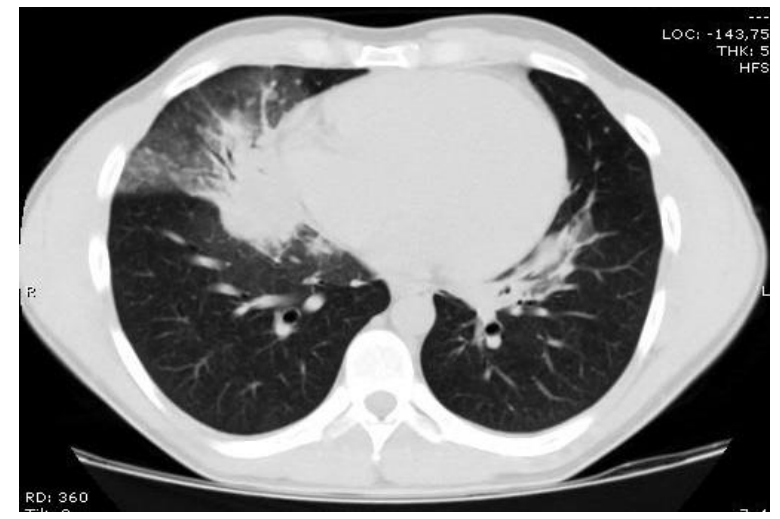

causal; o tratamento de suporte e das complicações, nomeadamente sobreinfecção bacteriana. 0 uso de corticóides é controverso devendo ser reservado para as situação clínicas mais graves ${ }^{1-2}$.

No nosso caso não foi possível constatar os macrófagos típicos no LB. Atendendo à evolução favorável, pareceu-nos desnecessário expor 0 doente a métodos mais invasivos, até porque a história clínica e os achados imagiológicos característicos apoiam fortemente 0 diagnóstico.

\section{Bibliografía}

1. Marchiori E, Zanetti G, Mano CM, Hochhegger B. Exogenous lipoid pneumonia. Clinical and radiological manifestations. Respir Med, 2011; 105(5): 659-66

2. Pielaszkiewicz-Wydra M, Homola-Piekarska B, et al. Exogenous lipoid pneumonia - a case report of a fire-eater. Pol J Radiol, 2012; 7(4):60-4.

3. Gondouin A, Manzoni P, Ranfaing E et al. Exogenous lipoid pneumonia: a retrospective multicentre study of 44 cases in France. Eur Respir J, 1996; 9: 1463-9

4. Betancourt SL, Martinez-Jimenez S, Rossi SE, Truong MT, Carrillo J, Erasmus JJ. Lipoid pneumonia: spectrum of clinical and radiologic manifestations. AJR Am J Roentgenol 2010; 194:103-9

\section{Diagnóstico: Pulmão do Cuspidor de Fogo}

Rute M. Ferreira, J. Vasco Barreto

Serviço de Medicina Interna do Hospital Pedro Hispano,

Unidade Local de Saúde de Matosinhos. Portugal

Correspondencia: rutecat.morais@gmail.com

Como citar este artículo: Ferreira RM, Vasco Barreto J

Pulmão do Cuspidor de Fogo. Galicia Clin 2014; 75 (1): 44

Recibido: 4/11/2013; Aceptado: 19/12/2013 